Biocatalysis and Biotransformation

\title{
$\beta$-xylosidase from Selenomonas ruminantium: Immobilization, stabilization, and application for xylooligosaccharide hydrolysis
}

\section{César Rafael Fanchini Terrasan, Caio Casale Aragon, Douglas Chodi Masui, Benevides Costa Pessela, Gloria Fernandez-Lorente, Eleonora Cano Carmona \& Jose Manuel Guisan}

To cite this article: César Rafael Fanchini Terrasan, Caio Casale Aragon, Douglas Chodi Masui, Benevides Costa Pessela, Gloria Fernandez-Lorente, Eleonora Cano Carmona \& Jose Manuel Guisan (2016) $\beta$-xylosidase from Selenomonas ruminantium: Immobilization, stabilization, and application for xylooligosaccharide hydrolysis, Biocatalysis and Biotransformation, 34:4, 161-171, DOI: $10.1080 / 10242422.2016 .1247817$

To link to this article: https://doi.org/10.1080/10242422.2016.1247817

曲 Published online: 21 Nov 2016.

Submit your article to this journal

山 Article views: 82

View Crossmark data $[\pi$

Citing articles: 3 View citing articles $匚 7$ 


\title{
$\beta$-xylosidase from Selenomonas ruminantium: Immobilization, stabilization, and application for xylooligosaccharide hydrolysis
}

\author{
CÉSAR RAFAEL FANCHINI TERRASAN ${ }^{1}$ (D), CAIO CASALE ARAGON ${ }^{1}$ (D), \\ DOUGLAS CHODI MASUI $^{1}{ }^{1}$, BENEVIDES COSTA PESSELA ${ }^{2}$ (D), \\ GLORIA FERNANDEZ-LORENTE ${ }^{2}$ (D), ELEONORA CANO CARMONA ${ }^{3}$ (D) \\ \& JOSE MANUEL GUISAN ${ }^{1}$ (D)
}

\begin{abstract}
${ }^{1}$ Departamento de Biocatálisis, Instituto de Catálisis y Petroleoquimica (ICP), Consejo Superior de Investigaciones Cientificas (CSIC), Campus Universidad Autónoma de Madrid (UAM), Madrid, Spain, ${ }^{2}$ Departamento de Biotecnología y Microbiología de Alimentos, Instituto de Investigación en Ciencias de los Alimentos (CIAL), Consejo Superior de Investigaciones Científicas (CSIC), Campus Universidad Autónoma de Madrid (UAM), Madrid, Spain, and ${ }^{3}$ Biochemistry and Microbiology Department, Biosciences Institute, Univ Estadual Paulista - UNESP, Rio Claro, São Paulo, Brazil
\end{abstract}

\begin{abstract}
The tetrameric $\beta$-xylosidase from Selenomonas ruminantium is very stable in alkaline $\mathrm{pH}$ allowing it to easily immobilize by multipoint covalent attachments on highly activated glyoxyl agarose gels. Initial immobilization resulted only in slight stabilization in relation to the free enzyme, since involvement of all subunits was not achieved. Coating the catalyst with aldehydedextran or polyethylenimine, fully stabilized the quaternary structure of the enzyme rendering much more stabilization to the biocatalyst. The catalyst coated with polyethylenimine of molecular weight 1300 is the most stable one exhibiting an interesting half-life of more than 10 days at $\mathrm{pH} 5.0$ and $50^{\circ} \mathrm{C}$, being, therefore, 240-fold more stable than free enzyme. Optimum activity was observed in the $\mathrm{pH}$ range $4.0-6.0$ and at $55^{\circ} \mathrm{C}$. The catalyst retained its side activity against $p$-nitrophenyl $\alpha$-Larabinofuranoside and it was inhibited by xylose and glucose. Kinetic parameters with $p$-nitrophenyl $\beta$-D-xylopyranoside as substrate were $V_{\max } 0.20 \mu \mathrm{mol} . \mathrm{min}^{-1} \mathrm{mg}$ prot. $^{-1}, K_{\mathrm{m}} 0.45 \mathrm{mM}, K_{\text {cat }} 0.82 \mathrm{~s}^{-1}$, and $K_{\text {cat }} / K_{\mathrm{m}} 1.82 \mathrm{~s}^{-1} \mathrm{mM}^{-1}$. Xylose release was observed from the hydrolysis of xylooligosaccharides with a decrease in the rate of xylose release by increasing substrate chainlength. Due to the high thermostability and the complete stability after five reuse cycles, the applicability of this biocatalyst in biotechnological processes, such as for the degradation of lignocellulosic biomass, is highly increased.
\end{abstract}

Keywords: $\beta$-xylosidase, Selenomonas ruminantium, enzyme immobilization, enzyme stabilization, xylooligosaccharide hydrolysis

\section{Introduction}

Xylan is the second most abundant biopolymer in the plant cell walls and the main hemicellulosic polysaccharide. It is composed of a $\beta(1 \rightarrow 4)$-Dxylopyranose backbone substituted, at varying degrees, by side chain residues as glucopyranosyl, 4-O-methyl-D-glucuronopyranosyl, $\alpha$-L-arabinofuranosyl, acetyl, feruloyl, and $p$-coumaroyl (Saha 2003). The complete hydrolysis of xylan requires the synergistic action of various enzymes, known as a xylanolytic system (Biely 1985). Endo- $\beta-1,4$-xylanase (E.C. 3.2.1.8) and $\beta$-D-xylosidase (E.C. 3.2.1.37) are the main enzymes in the degradation of the polymer. Xylanases cleave internal $\beta(1 \rightarrow 4)$ bonds in the xylan backbone liberating xylooligosaccharides, and $\beta$-xylosidases are exoglycosidases that remove xylose from the nonreducing ends of these xylooligosaccharides.

\footnotetext{
Correspondence: César Rafael Fanchini Terrasan, Departamento de Biocatálisis, Instituto de Catálisis y Petroleoquimica (ICP), Consejo Superior de Investigaciones Científicas (CSIC), Campus Universidad Autónoma de Madrid (UAM), Cantoblanco, Calle de Marie Curie 28049, Madrid, Spain. E-mail: cesarterrasan@hotmail.com
}

(Received 25 fuly 2015; revised 26 fanuary 2016; accepted 19 August 2016)

ISSN 1024-2422 print/ISSN 1029-2446 online (C) 2016 Informa UK Limited, trading as Taylor \& Francis Group DOI: $10.1080 / 10242422.2016 .1247817$ 
Finally, $\alpha$-L-arabinofuranosidases, acetyl xylan- and ferulic or $p$-coumaric acid esterases are enzymes responsible for removing side chains of the polymer (Collins et al. 2005).

The interest and application of xylan degrading enzymes in different industries have increased over the last decades. $\beta$-xylosidase is used on industrial scale included in xylanases cocktails for the bioconversion of lignocellulosic material to sugars and other useful substances, clarification of juices and wines, biobleaching in the pulp and paper industries and in processing of fabrics. $\beta$-xylosidases are critical for the systems since they carry the greatest work load in terms of number of glycosidic bonds cleaved, as well as in relieving product inhibition of xylanases (Jordan and Wagschal 2010) and cellulases (Zhang and Viikari 2012). Thus, its performance is of primary importance especially when these enzymes are applied together in processes aiming the complete saccharification of lignocellulosic biomass.

The $\beta$-xylosidase from the ruminal anaerobic bacterium Selenomonas ruminantium is a very well characterized enzyme, corresponding to a bifunctional $\beta$-D-xylosidase $/ \alpha$-L-arabinofuranosidase glycoside hydrolase belonging to family 43 (GH 43) and structural clan $\mathrm{F}$ in the CAZy database. The enzyme is a homotetramer in solution, with MW of approximately $60 \mathrm{kDa}$ of each subunit. It shows a $\mathrm{p} I$ of 4.4, $\mathrm{pH}$ stability in the range from 4.3 to 10.0 and stability up to $50^{\circ} \mathrm{C}$ in pH 5.3 for $1 \mathrm{~h}$ (Jordan et al. 2007b; Jordan 2008; Jordan and Wagschal 2010).

Currently, the main concern is the rational use of $\beta$-xylosidases for the complete hydrolysis of xylooligosaccharides to the final product, D-xylose. Enzyme immobilization poses as a possibility to improve the characteristics of an enzyme in terms of stability, stabilization, and catalysis, as well as for processes improvement since it allows the reuse of the biocatalyst for many operational cycles (Mateo et al. 2007). Many $\beta$-xylosidases have been produced and characterized (Knob et al. 2010) and some studies have evaluated covalent immobilization of these enzymes as that from Talaromyces thermophilus (Guerfali et al. 2009) immobilized on chitosan or that from Trichoderma reesei QM 9414 immobilized on nylon powder (Dueñas and Estrada 1999). Nevertheless, to our knowledge, there is no report about the immobilization of $\beta$-xylosidases by multipoint covalent immobilization using agarose gels activated with glyoxyl groups as support.

The aim of this study was to immobilize the $\beta$-xylosidase from Selenomonas ruminantium by multipoint covalent immobilization, evaluate some physicochemical properties of the immobilized enzyme and also verify its performance on the hydrolysis of xylooligosaccharides.

\section{Materials and methods}

\section{Materials}

Agarose 4BCL was purchased from Agarose Bead Technologies (Madrid, Spain). $p$-nitrophenyl $\beta$-Dxylopyranoside ( $p$ NPX), $p$-nitrophenyl $\alpha$-L-arabinofuranoside ( $p$ NPAra), xylose, glycidol, potassium tetraborate tetrahydrate, sodium borohydride, sodium periodate, ethanolamine, Leuconostocc spp dextran (MW 1500-70,000), polyethylenimine (PEI, MW 1300-1 $\times 10^{6}$ ) and molecular weight standard proteins were obtained from Sigma-Aldrich Co. (St. Louis, MO). Cyanogen bromide (CNBr) Sepharose $4 \mathrm{~B}$ and low molecular weight standard proteins were purchased from GE Healthcare (Uppsala, Sweden). Selenomonas ruminantium $\beta$-xylosidase (Lot 100301a) and standards xylooligosaccharides (DP 2-6) were purchased from Megazyme (Wicklow, Ireland). All reagents were of analytical grade. Xylobiose and xylooligosaccharides (xylotriose and larger than six residues xylooligosaccharides) from beechwood xylan (Sigma-Aldrich Co., St. Louis, $\mathrm{MO}$ ) and from Cannabis spp xylan (obtained locally from textile industry) were prepared in our laboratory by enzymatic hydrolysis with the purified xylanase from Humicola brevis var. thermoidea (Masui et al. 2012).

\section{Methods}

All results represent the average of three experiments. The experimental error was lower than $5 \%$.

\section{Enzyme assay and protein determination}

Standard $\beta$-xylosidase activity assays were carried out in a reaction mixture containing $5 \mathrm{mM} p \mathrm{NPX}$ in $0.05 \mathrm{M}$ sodium acetate buffer $\mathrm{pH} 5.0$ and appropriately diluted enzyme solution or catalyst suspension to $1 \mathrm{ml}$ final volume. The reaction was stopped with $1 \mathrm{ml}$ of a saturated potassium tetraborate solution and the absorbance was read at $405 \mathrm{~nm}$ (KerstersHilderson et al. 1982). One unit of activity was defined as the amount of enzyme required to release $1 \mu \mathrm{mol}$ of product equivalent per min in the assay conditions at $25^{\circ} \mathrm{C}\left(\varepsilon=18,300 \mathrm{M}^{-1} \mathrm{~cm}^{-1}\right)$.

Protein concentration was determined with the modified Bradford's method, with bovine serum albumin as standard (Sedmak and Grossberg 1977).

\section{Preparation of glyoxyl-agarose support}

A mass of $105 \mathrm{~g}$ of $4 \%$ cross-linked agarose beads was suspended in water to a final volume of $180 \mathrm{ml}$ $(0.7 \mathrm{~g}$ of agarose is roughly equivalent to $1 \mathrm{ml})$. 
After mild homogenization, $50 \mathrm{ml}$ of $1.7 \mathrm{M} \mathrm{NaOH}$ containing $1.425 \mathrm{~g}$ of $\mathrm{NaBH}_{4}$ was slowly added. In an ice bath, $36 \mathrm{ml}$ of glycidol was added drop-wise and the mixture was then gently stirred at room temperature for $18 \mathrm{~h}$. After this period, the gel was finally washed with an excess of distilled water. Then, the wet glyceryl-activated gel was oxidized with aqueous $\mathrm{NaIO}_{4}$ solution under very gentle stirring. After $2 \mathrm{~h}$, the gel was washed with distilled water, vacuum dried (maintaining the pores of agarose gels filled with water) and stored at $4{ }^{\circ} \mathrm{C}$ (Guisán 1988).

\section{Preparation of aldehyde-dextran}

Leuconostoc spp dextran (MW 1500-70,000) was fully oxidized by adding $4.36 \mathrm{~g}$ of sodium periodate to $50 \mathrm{ml}$ of an aqueous suspension containing $1.67 \mathrm{~g}$ dextran. The suspension was gently agitated by $2 \mathrm{~h}$ and then dialyzed $(4 \times)$ against distilled water.

\section{Stability of soluble enzyme at pH 10.0}

The enzyme was 400 -fold diluted in $0.1 \mathrm{M}$ sodium bicarbonate buffer $\mathrm{pH}$ 10.0. The solution was incubated at $25^{\circ} \mathrm{C}$, and aliquots were withdrawn at different intervals and the activity was assayed as previously described.

\section{Enzyme immobilization}

Immobilization on glyoxyl agarose: the $S$. ruminantium $\beta$-xylosidase was 400 -fold diluted in $10 \mathrm{ml}$ of $0.1 \mathrm{M}$ sodium bicarbonate buffer $\mathrm{pH} 10.0$ at $4{ }^{\circ} \mathrm{C}$. The solution $(0.31 \mathrm{~g}$ prot./l) was added to $1 \mathrm{~g}$ of glyoxyl agarose support, and the suspension was gently stirred at $25^{\circ} \mathrm{C}$. The period of immobilization was determined after carrying out this procedure by 0.5 and $14 \mathrm{~h}$. Both supernatant and suspension samples were withdrawn periodically and the enzyme activity was measured. After these periods, catalysts were reduced by adding $10 \mathrm{mg}$ of sodium borohydride for $30 \mathrm{~min}$, then washed with water and filtered under vacuum.

Dextran-coated catalysts: a mass of $0.5 \mathrm{~g}$ of the uncoated catalyst (immobilization carried out by $0.5 \mathrm{~h}$, as described above) was added to $5 \mathrm{ml}$ of aldehyde-dextran suspensions, $\mathrm{pH}$ adjusted to 7.0. Dextrans with MW of 1500, 6000, 25,000, and $75,000 \mathrm{Da}$ were evaluated. The suspensions were gently agitated overnight, then $5 \mathrm{ml}$ of $0.1 \mathrm{M}$ sodium bicarbonate buffer $\mathrm{pH} 10.0$ was added and the catalysts were reduced by adding $10 \mathrm{mg}$ of sodium borohydride for $30 \mathrm{~min}$, washed abundantly with water and filtered under vacuum.

PEI-coated catalysts: a mass of $0.5 \mathrm{~g}$ of the uncoated catalyst (immobilization carried out by
$0.5 \mathrm{~h}$, as described above) was added to $5 \mathrm{ml}$ of $5 \%$ (w/v) PEI solutions, $\mathrm{pH}$ adjusted to 7.0. PEI with MW of 1300, 25,000, 75,000, and 600,000$1 \times 10^{6} \mathrm{Da}$ was evaluated. The suspensions were gently agitated overnight, washed abundantly with water and filtered under vacuum.

Immobilization on CNBr-activated Sepharose: it was performed in very mild conditions by using a $100 \times$ diluted enzyme solution in $0.1 \mathrm{M}$ sodium phosphate buffer pH 7.0 at $4{ }^{\circ} \mathrm{C}$. After $15 \mathrm{~min}$, the catalyst was filtered and suspended in $10 \mathrm{ml}$ of a $1 \mathrm{M}$ ethanolamine solution $\mathrm{pH} 8.0$ for $2 \mathrm{~h}$ to block any remaining reactive group, according to the supplier.

The immobilization yield was defined as the ratio between the activities (or protein) in the supernatant compared with the activity (or protein) in the control. Expressed activity was defined as the ratio of the activity in the final suspension after the immobilization process and the initial activity of offered enzyme.

\section{Optimum $\mathrm{pH}$ and temperature}

Optimum $\mathrm{pH}$ was determined by assaying $\beta$-xylosidase activity at $25^{\circ} \mathrm{C}$ at various $\mathrm{pH}$ in the range from 4.0 to 9.0. The following buffers were utilized: $0.05 \mathrm{M}$ sodium acetate buffer $\mathrm{pH} 4.0$ and 5.0, $0.05 \mathrm{M}$ sodium phosphate buffer $\mathrm{pH} 6.0$ and 7.0, and $0.05 \mathrm{M}$ Tris $\mathrm{HCl}$ buffer $\mathrm{pH} 8.0$ and 9.0.

Optimum temperature was determined by assaying $\beta$-xylosidase activity at temperatures ranging from 35 to $60^{\circ} \mathrm{C}$, with $5^{\circ} \mathrm{C}$ intervals, in $0.05 \mathrm{M}$ sodium acetate buffer $\mathrm{pH}$ 5.0.

\section{Thermal stability}

A mass of $0.1 \mathrm{~g}$ of each catalyst was suspended in $1.0 \mathrm{ml}$ of $0.05 \mathrm{M}$ acetate buffer $\mathrm{pH} 5.0$ and incubated at 50 and $55^{\circ} \mathrm{C}$. In all cases, samples of the suspension were withdrawn at several intervals and the activity was assayed as previously described. Residual activity was calculated as the ratio between activity at a given time and the activity in the beginning of incubation.

\section{pH stability}

A mass of $0.1 \mathrm{~g}$ of each catalyst was suspended in $1.0 \mathrm{ml}$ of different buffers to compose the $\mathrm{pH}$ range from 4.0 to 9.0. The following buffers were utilized: $0.05 \mathrm{M}$ acetate buffer for $\mathrm{pH} 4.0$ and $5.0,0.05 \mathrm{M}$ phosphate buffer for $\mathrm{pH} 6.0$ and 7.0, and $0.05 \mathrm{M}$ Tris $\mathrm{HCl}$ buffer $\mathrm{pH}$ and 8.0 and 9.0. The suspension was incubated at $50^{\circ} \mathrm{C}$. Samples were withdrawn at several intervals and the activity was assayed as 
previously described. Residual activity was calculated as the ratio between activity at a given time and the activity in the beginning of incubation.

\section{Specificity and kinetics}

The specificity of the catalyst was verified by assaying the activity against $0.04 \mathrm{M} p \mathrm{NPAra}$ in $0.05 \mathrm{M}$ sodium acetate buffer $\mathrm{pH} 5.0$ at $25^{\circ} \mathrm{C}$. The results were expressed in relation to the activity on $p$ NPX. Kinetics of the free and immobilized enzyme was carried out by assaying $\beta$-xylosidase activity with $p$ NPX $(0.1-3 \mathrm{mM})$ in $0.1 \mathrm{M}$ succinate- $\mathrm{NaOH}$ buffer $\mathrm{pH} 5.3$ at $25^{\circ} \mathrm{C}$. Maximum velocity $\left(V_{\max }\right)$ and Michaelis-Menten constant $\left(K_{\mathrm{m}}\right)$ were calculated with MMfit version 1.3.0 (2013, J.P.G. Malthouse). Protein concentration of $31 \mathrm{gl}^{-1}$ and $0.95 \mathrm{mg} \mathrm{g}$ biocatalyst $^{-1}$ for the free and immobilized enzyme, respectively, was used to calculate $K_{\text {cat }}$.

\section{$S D S-P A G E$}

SDS-PAGE was performed in $8 \%(\mathrm{w} / \mathrm{v})$ gels (Laemmli 1970). The resolved protein bands were visualized after staining with $0.1 \%(\mathrm{w} / \mathrm{v})$ Coomassie brilliant blue R-250 dissolved in methanol, acetic acid, and distilled water $(4: 1: 5, \mathrm{v} / \mathrm{v} / \mathrm{v})$. Standard proteins were phosphorylase $\mathrm{b}(97 \mathrm{kDa})$, bovine serum albumin $(66 \mathrm{kDa})$, ovalbumin $(45 \mathrm{kDa})$, carbonic anhydrase $(30 \mathrm{kDa})$, trypsin inhibitor $(20.1 \mathrm{kDa})$, and $\alpha$-lactalbumin $(14.4 \mathrm{kDa})$.

\section{Hydrolysis of xylooligosaccharides and analysis of the} products

Solutions of xylotetraose, xylopentaose, xylotetrose, xylopentose, and xylohexaose $(0.5 \mathrm{~g} / \mathrm{l})$ were prepared in $5 \mathrm{mM}$ sodium acetate buffer $\mathrm{pH}$ 5.0. The PEIcoated glyoxyl catalyst was added $(50 \mathrm{mg}$ to $5 \mathrm{ml}$ reaction medium) and hydrolysis of each substrate was carried out at $50^{\circ} \mathrm{C}$, under magnetic stirring (300 rpm), and samples were taken at several interval times.

The hydrolysis of beechwood and Cannabis spp xylans was carried out by Humicola brevis var. thermoidea xylanase immobilized on glyoxyl agarose. After 3 days, the medium was filtered and the supernatant containing xylobiose, xylotriose, xylooligosaccharides with DP $>6$, and non-hydrolyzed xylan (unpublished data) was submitted to a second enzymatic hydrolysis with $S$. ruminantium immobilized $\beta$-xylosidase (PEI-coated glyoxyl catalyst). The hydrolysis was carried out for $120 \mathrm{~min}$ in $0.05 \mathrm{M}$ sodium acetate buffer pH 5.0 (200 mg catalyst to $10 \mathrm{ml}$ reaction) at $25^{\circ} \mathrm{C}$.

\section{Analysis of hydrolysis products by high-performance} liquid chromatography

High-performance liquid chromatography (HPLC) was coupled with low-temperature evaporative lightscattering detection LT-ELSD using a detector Sedex75 (Sedere, Orleans, France). Analyses were carried out at $80^{\circ} \mathrm{C}$ on a Rezec R50-oligosaccharide $\mathrm{Ag}^{+} 4 \%$ column $(200 \times 10 \mathrm{~mm})$ (Phenomenex, Torrance, CA). The elution was carried out with Milli-Q ultrapure apyrogenic water at a $0.3 \mathrm{ml} / \mathrm{min}$ flow rate using a TSP P100 pump and AS3000 auto sampler Spectra Series (Thermo Electron Co., San Jose, CA). Data acquisition and processing was performed using the Chromquest 4.1 software (Thermo Electron Co., San Jose, CA). The quantification of products was based on an external calibration using standard xylose, xylobiose, and XOS solutions (DP 3-6). Samples of each hydrolyzed substrate were previously centrifuged $(10,000 \times g$, $20 \mathrm{~min})$, filtered $(0.22 \mu \mathrm{m}$ filters $)$ and the adequately diluted supernatant was analyzed. Analyses were carried out in duplicate and data were expressed as mean value.

\section{Reuse of the catalyst and storage}

Reuse was verified by suspending the PEI-coated glyoxyl catalyst plus inert agarose in $3 \mathrm{mM} p \mathrm{NPX}$ (in $0.05 \mathrm{M}$ sodium acetate buffer at $\mathrm{pH}$ 5.0) at the proportion 1:49:100 (w/w/v). Successive batch hydrolysis cycles were carried out for $1 \mathrm{~h}$ at $25^{\circ} \mathrm{C}$ under magnetic stirring $(300 \mathrm{rpm})$. After each cycle, the catalyst was washed three times with $0.05 \mathrm{M}$ sodium acetate buffer $\mathrm{pH}$ 5.0, filtered under vacuum and re-suspended in the same buffer $(1: 10, \mathrm{w} / \mathrm{v})$ to measure residual activity. Then it was filtered under vacuum again and new substrate was added for the following cycle. In order to verify the stability after long-term storage, the catalyst was maintained in sealed flasks at $4{ }^{\circ} \mathrm{C}$. After 6 months, the catalyst was re-suspended in $0.05 \mathrm{M}$ sodium acetate buffer $\mathrm{pH}$ 5.0 and the residual activity was assayed.

\section{Results}

\section{Immobilization}

The soluble $\beta$-xylosidase from Selenomonas ruminantium was very stable in $\mathrm{pH} 10.0$, maintaining $100 \%$ of its activity up to $3 \mathrm{~h}$-incubation in this condition. After $20 \mathrm{~h}, 57 \%$ of the activity was still observed (not shown). The high stability allowed the enzyme to be submitted to multipoint covalent immobilization at this $\mathrm{pH}$, an ideal condition for the immobilization on glyoxyl. Initially, a catalyst was prepared by carrying 
out immobilization for $0.5 \mathrm{~h}$. No activity was detected in the final supernatant and the process presented $71.4 \%$ yield based on initial activity. Despite the $100 \%$ protein immobilization observed after this period, a second catalyst was prepared by carrying out immobilization during $15 \mathrm{~h}$.

In a third stage, the catalyst prepared for $0.5 \mathrm{~h}$ immobilization was incubated with polymers, i.e., different MW dextran and PEI in order to coat the enzyme surface. The coating procedure and/or the second sodium borohydride reduction (dextran coated catalysts) caused some loss in the activity and the coated catalysts maintained $65 \%$ of the activity observed in the non-coated catalyst.

Soluble enzyme was the first control and the $\mathrm{CNBr}$ catalyst, corresponding to a one point immobilized enzyme, was a second control.

\section{Catalysts characterization}

Despite the possibility to obtain higher stability, the catalyst prepared with $15 \mathrm{~h}$ immobilization was less stable than that prepared by $0.5 \mathrm{~h}$ immobilization (Figure 1). In fact, the half-life of this catalyst $(0.5 \mathrm{~h})$ was even lower than those observed for the free enzyme $(1 \mathrm{~h})$ and the $\mathrm{CNBr}$ catalyst $(2 \mathrm{~h})$ at $50^{\circ} \mathrm{C}$. At this temperature, the glyoxyl catalyst prepared by $0.5 \mathrm{~h}$ immobilization presented half-life of $7 \mathrm{~h}$, and thus it was 7- and 3.5-fold stabilized in relation to the free enzyme and the $\mathrm{CNBr}$ catalyst, respectively. Due to the considerable stabilization obtained, this catalyst was chosen for the subsequent experiments.

The stability of the dextran-coated catalysts at $50^{\circ} \mathrm{C}$ (Figure 2) was indirectly related to the MW of dextran, i.e., the lowest thermostability was observed for the catalyst coated with MW 70,000 dextran, presenting half-life lower than $30 \mathrm{~min}$, while the highest thermostability was observed with MW 1500 dextran. This catalyst retained more than $50 \%$ of the activity after 5 days, indicating low MW dextrans to be better in adequately coating the enzyme subunits. Intermediate half-life values, between 1 and $2 \mathrm{~h}$, were observed for the catalysts coated with MW 6000 and 25,000 dextrans.

The PEI-coated catalysts were all highly stabilized. The stabilization with PEI was similar to that obtained with the catalyst coated with MW 1500 dextran, although the size of the polymer had low influence on enzyme thermostability (Figure 3). Catalysts coated with PEI MW 1300 and 25,000 were more stable maintaining around $60 \%$ of the activity while the others maintained around 50\% after 5 days. If considering these two latter catalysts maintained around $50 \%$ of the activity after 5 days of incubation at $50^{\circ} \mathrm{C}$, the enzyme was therefore 120 - and 60 -fold stabilized in relation to the free enzyme and the $\mathrm{CNBr}$ catalyst, respectively. The stabilization of the catalyst coated with PEI MW 1300 was much higher (more than 240-fold in relation to the free enzyme) since $52 \%$ of the activity was observed even after 10 days of incubation.

Comparing the stability at $55^{\circ} \mathrm{C}$, the catalyst coated with dextran MW 1500 was sparingly stable, while the catalyst coated with PEI MW 1300 presented half-life of $40 \mathrm{~min}$ (not shown). At this temperature and in different $\mathrm{pH}$, the highest

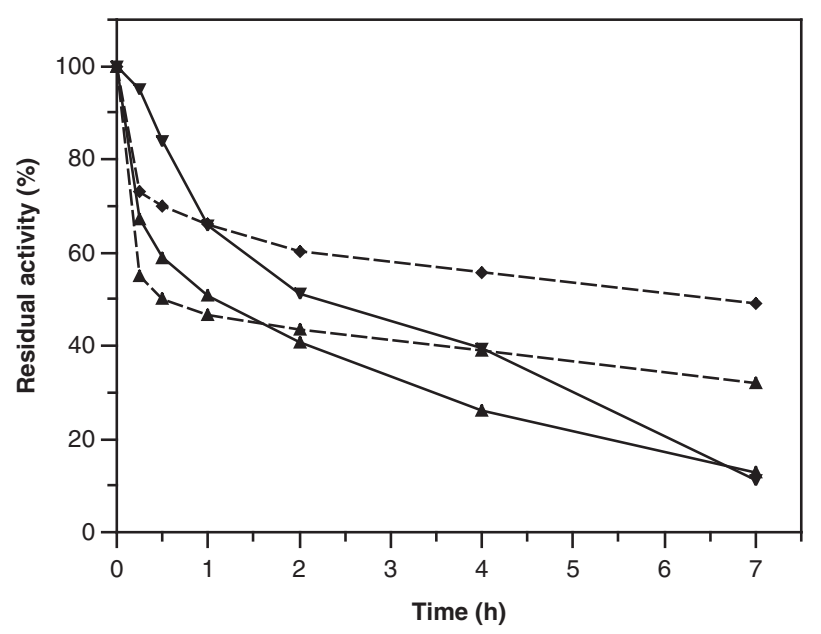

Figure 1. Thermostability of the free $\beta$-xylosidase from $S$. ruminantium and its catalysts. The incubation was carried out in $0.05 \mathrm{M}$ sodium acetate buffer $\mathrm{pH} 5.0$ at $50^{\circ} \mathrm{C}$ and the activity was assayed in the same buffer at $25^{\circ} \mathrm{C}$. Dash lines: $\beta$-xylosidase activity of glyoxyl catalysts with immobilization carried out by $0.5 \mathrm{~h}$ $(\downarrow)$ and $15 \mathrm{~h}(\boldsymbol{\Lambda})$. Solid lines: $\beta$-xylosidase activity of free enzyme $(\boldsymbol{\Delta})$ and $\mathrm{CNBr}$ catalyst $(\boldsymbol{\nabla})$.

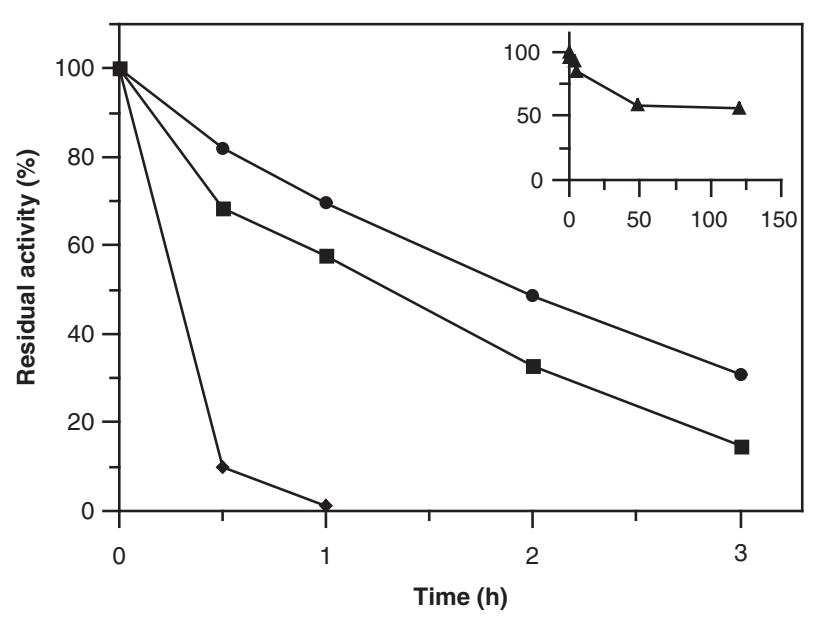

Figure 2. Thermostability of the dextran-coated glyoxyl catalysts of the $\beta$-xylosidase from $S$. ruminantium. The incubation was carried out in $0.05 \mathrm{M}$ sodium acetate buffer $\mathrm{pH} 5.0$ at $50^{\circ} \mathrm{C}$, and the activity was assayed in the same buffer at $25^{\circ} \mathrm{C}$. $\beta$-xylosidase activity of catalysts coated with dextrans of MW 1500 ( $\boldsymbol{\Lambda}$, in detail), $6000(\bullet), 25,000(\boldsymbol{\square})$ and 70,000 ( $)$. 


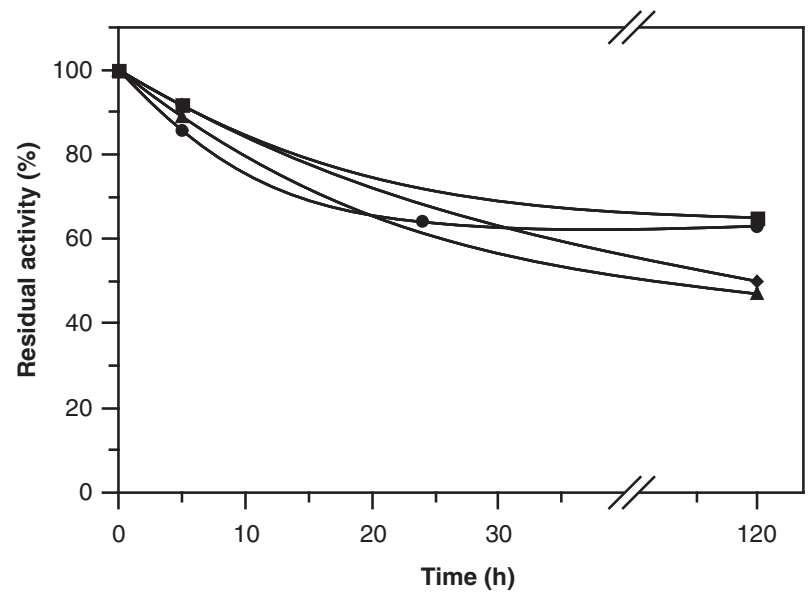

Figure 3. Thermostability of the PEI-coated glyoxyl catalyst of the $\beta$-xylosidase from $S$. ruminantium. The incubation was carried out in $0.05 \mathrm{M}$ sodium acetate buffer $\mathrm{pH} 5.0$ at $50^{\circ} \mathrm{C}$, and the activity was assayed in the same buffer at $25^{\circ} \mathrm{C}$. $\beta$-xylosidase activity of catalysts coated with PEI MW $1300(\bullet), 25,000(\boldsymbol{\square})$, 75,000 (•), and $600,000-1 \times 10^{6}(\mathbf{\Delta})$.

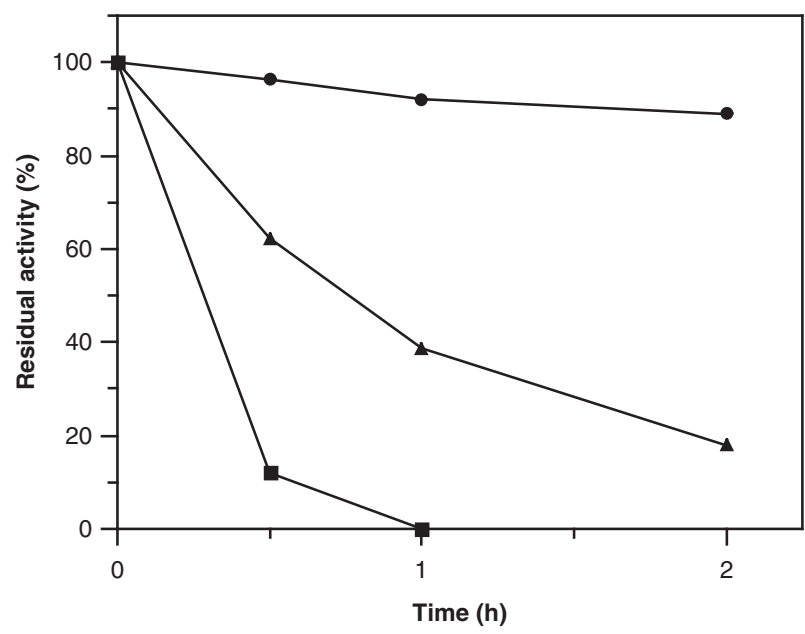

Figure 4. Stability at different $\mathrm{pH}$ values of the PEI-coated glyoxyl catalyst of the $\beta$-xylosidase from $S$. ruminantium. The incubation was carried out at $55^{\circ} \mathrm{C}$ in $0.05 \mathrm{M}$ sodium acetate buffer $\mathrm{pH} 4.0$ $(\bullet)$ and $5.0(\boldsymbol{\Delta})$, and $0.05 \mathrm{M}$ sodium phosphate buffer $\mathrm{pH} 6.0$ (ם). The activity was assayed in $0.05 \mathrm{M}$ sodium acetate buffer $\mathrm{pH}$ 5.0 at $25^{\circ} \mathrm{C}$.

thermostability of the PEI-coated glyoxyl catalyst was verified in $\mathrm{pH} 4.0$, i.e. after $2 \mathrm{~h}$ the remaining activity still was around $90 \%$. The lowest stability was verified in $\mathrm{pH}$ 6.0, while intermediate half-life value was observed in $\mathrm{pH} 5.0$ (Figure 4).

When the catalysts were incubated under denaturing conditions, it can be observed that the enzyme was partially covalently immobilized since bands of the enzyme subunits were observed. Full stabilization of quaternary structure was only obtained after coating the surface of the biocatalyst with dextran (Figure 5). Considering this results

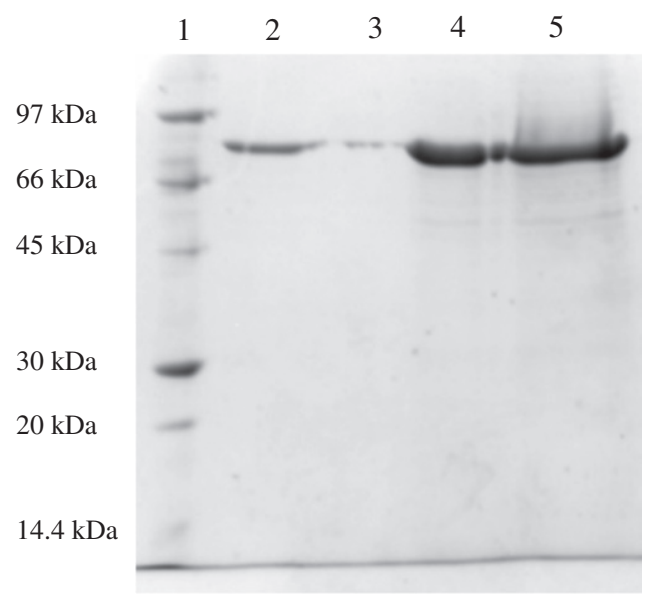

Figure 5. SDS-PAGE of the free $\beta$-xylosidase from $S$. ruminantium and its catalysts. Row 1: Standard proteins: phosphorylase b $(97 \mathrm{kDa})$, bovine serum albumin $(66 \mathrm{kDa})$, ovalbumin $(45 \mathrm{kDa})$, carbonic anhydrase $(30 \mathrm{kDa})$, trypsin inhibitor $(20.1 \mathrm{kDa})$, and $\alpha$-lactalbumin $(14.4 \mathrm{kDa})$, row 2 : uncoated glyoxyl catalyst (0.07 mg prot.), row 3: dextran-coated glyoxyl catalyst $(0.07 \mathrm{mg}$ prot.), row 4: $\mathrm{CNBr}$ catalyst ( $0.05 \mathrm{mg}$ prot.), row 5 : free enzyme (0.2 mg prot.).

and the higher stability indicate that low MW aldehyde-dextran and, similarly, different MW PEI are adequate to coat the immobilized enzyme, promoting the full stabilization of its quaternary structure.

Optimum activity of the catalysts was observed in the $\mathrm{pH}$ range from 4.0 to 6.0 , while the free enzyme presented optimum activity in $\mathrm{pH}$ 4.0. Besides, elevated activity of the immobilized enzyme, higher than $80 \%$, was observed in $\mathrm{pH} 7.0$, while the activity of the free enzyme was considerably lower (Figure 6a). Optimal temperature for the free enzyme and for the catalysts was observed at $50-55^{\circ} \mathrm{C}$ (Figure 6b). In addition, the side $\alpha$-L-arabinofuranosidase activity was preserved in the catalyst corresponding to $18 \%$ of the $\beta$-xylosidase activity.

Table 1 shows the different values obtained for the kinetic constants on $p$ NPX as substrate of the free and immobilized enzyme (PEI coated glyoxyl catalyst). The immobilized enzyme presented lower initial rates (Figure 7), resulting in $V_{\max }$ that is half of that observed for the free enzyme. $K_{\mathrm{m}}$ of $0.45 \mathrm{mM}$ observed for the immobilized enzyme was lower than the $0.72 \mathrm{mM}$ observed for the free enzyme, indicating the immobilized enzyme with higher affinity for the substrate.

The catalysts were also inhibited by xylose and glucose, being inhibition by xylose stronger than that by glucose. The PEI-coated catalyst and the free enzyme presented similar inhibition pattern and $\mathrm{CNBr}$ catalyst is a little more inhibited by xylose. In the presence of glucose, $\mathrm{CNBr}$ catalyst is a little more inhibited than the free enzyme and this effect is 

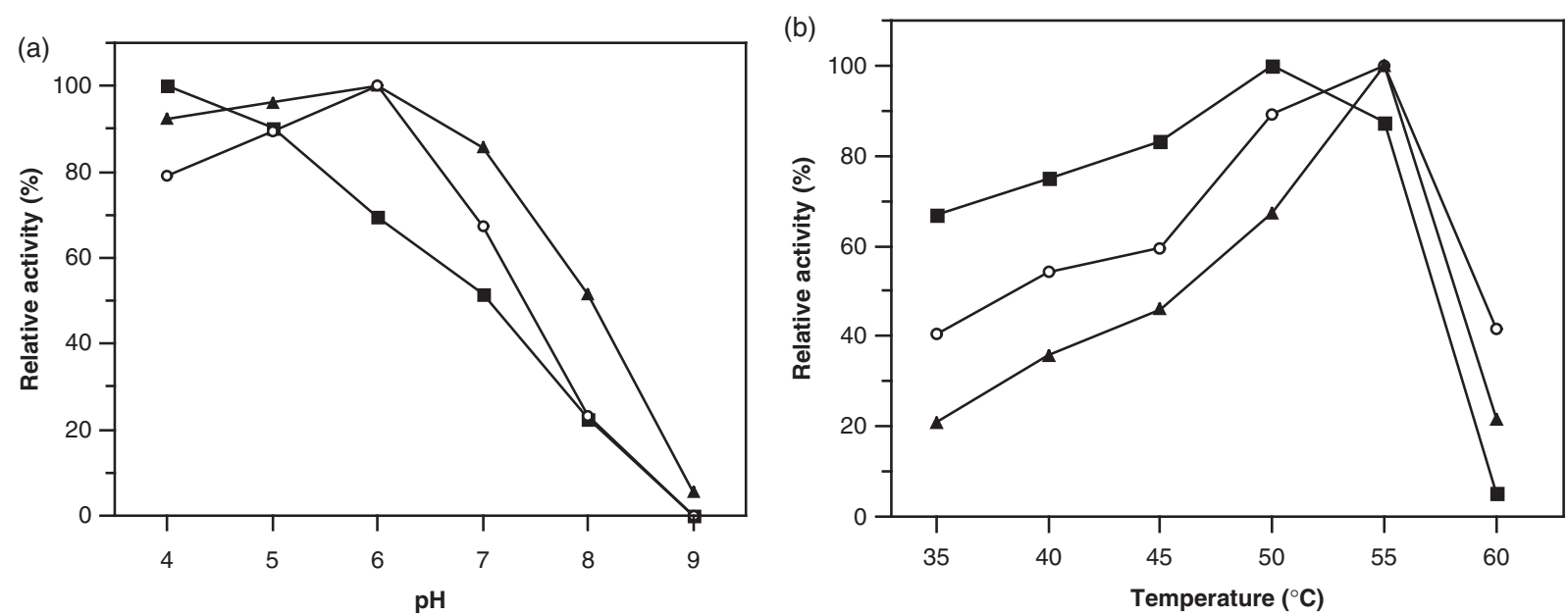

Figure 6. Activity profile at different $\mathrm{pH}$ values (a) and temperatures (b) of the free $\beta$-xylosidase from $S$. ruminantium and its catalysts. (a) The activity was assayed at $25^{\circ} \mathrm{C}$ in the following buffers: $0.05 \mathrm{M}$ sodium acetate buffer $\mathrm{pH} 4.0$ and 5.0; sodium phosphate buffer $\mathrm{pH} 6.0$ and 7.0; and Tris $\mathrm{HCl}$ buffer $\mathrm{pH} 8.0$ and 9.0. (b) The activity was assayed in $0.05 \mathrm{M}$ sodium acetate buffer $\mathrm{pH} 5.0$ at $35,40,45,50,55$, and $60^{\circ} \mathrm{C}$. PEI-coated glyoxyl catalyst $(\bigcirc), \mathrm{CNBr}$ catalyst $(\boldsymbol{\Delta})$, and free enzyme ( $\left.\mathbf{\square}\right)$.

Table 1. Kinetic parameters for the free and immobilized $\beta$-xylosidase from S. ruminantium.

\begin{tabular}{lllll}
\hline Enzyme & $V_{\max }\left(\mu \mathrm{mol} \mathrm{min}^{-1} \mathrm{mg} \mathrm{prot.}^{-1}\right)$ & $K_{\mathrm{m}}(\mathrm{mM})$ & $K_{\text {cat }}\left(\mathrm{s}^{-1}\right)$ & $K_{\text {cat }} / K_{\mathrm{m}}\left(\mathrm{s}^{-1} \mathrm{mM}^{-1}\right)$ \\
\hline Free & 0.43 & 0.72 & 1.83 & 2.47 \\
PEI-coated glyoxyl catalyst & 0.20 & 0.45 & 0.82 & 1.82 \\
\hline
\end{tabular}

The activity was assayed at different $p \mathrm{NPX}$ concentrations in $0.1 \mathrm{M}$ succinate- $\mathrm{NaOH}$ buffer $\mathrm{pH} 5.3$ at $25^{\circ} \mathrm{C}$.

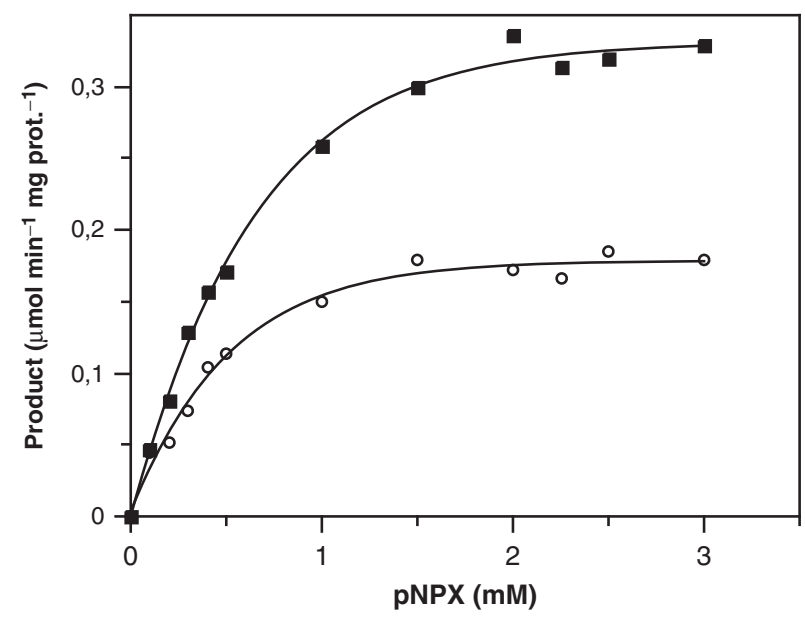

Figure 7. Saturation curves of initial velocity $\left(V_{0}\right)$ with $p$-nitrophenyl $\beta$-D-xylopyranoside for the free and immobilized $\beta$-xylosidase from $S$. ruminantium. The activity was assayed at different concentrations of $p \mathrm{NPX}$ in $0.1 \mathrm{M}$ succinate- $\mathrm{NaOH}$ buffer $\mathrm{pH} 5.3$ at $25^{\circ} \mathrm{C}$. PEI-coated glyoxyl catalyst $(\bigcirc)$ and free enzyme (

little more pronounced in the PEI-coated catalyst (Table 2). At $200 \mathrm{mM}$ glucose, the enzyme in the PEI-coated catalyst was more than $50 \%$ inhibited while the free enzyme was only a little more than $20 \%$ inhibited when using $p \mathrm{NPX}$ at $5 \mathrm{mM}$.
Table 2. Influence of xylose and glucose on the free $\beta$-xylosidase from $S$. ruminantium and its catalysts.

\begin{tabular}{llll}
\hline & \multicolumn{3}{l}{ Relative activity (\%) } \\
\cline { 2 - 4 } $\begin{array}{l}\text { Monosaccharide } \\
(\mathrm{mM})\end{array}$ & $\begin{array}{l}\text { PEI } \\
\text { catalyst }\end{array}$ & $\begin{array}{l}\text { CNBr } \\
\text { catalyst }\end{array}$ & $\begin{array}{l}\text { Free } \\
\text { enzyme }\end{array}$ \\
\hline Xylose & & & \\
0 & 100 & 100 & 100 \\
25 & 59.7 & 45.6 & 60.7 \\
50 & 46.5 & 35.8 & 42.6 \\
100 & 26.1 & 22.3 & 31.5 \\
150 & 21.6 & 16.0 & 20.7 \\
200 & 14.2 & 14.3 & 13.6 \\
Glucose & & & \\
0 & 100 & 100 & 100 \\
25 & 100 & 98.1 & 100 \\
50 & 93.2 & 92.5 & 100 \\
100 & 88.5 & 77.5 & 98.9 \\
150 & 81.9 & 67.8 & 89.7 \\
200 & 43.5 & 49.2 & 76.1 \\
\hline
\end{tabular}

The activity was assayed in $0.05 \mathrm{M}$ sodium acetate buffer $\mathrm{pH} 5.0$ at $25^{\circ} \mathrm{C}$.

\section{Hydrolysis of xylooligosaccharides}

The hydrolysis of various XOS by the PEI-coated glyoxyl catalyst was carried out in $\mathrm{pH} 5.0$ at $50^{\circ} \mathrm{C}$, and the reaction products were analyzed by HPLC. Xylose release was observed from all substrates over time, including from natural XOS. Productions of 0.19 and $0.07 \mathrm{~g} / 1$ were obtained from XOS derived 
from beechwood and Cannabis xylans, respectively. Product profile at different periods of the hydrolyzed substrates is presented in Table 3. As observed, the enzyme presented an exo-type action as the main product formed after a short period was always onexylosyl residue shorter than the incubated substrate. The rate of xylose release decreased with the substrate chain-length and, consequently, increased the period to obtain complete conversion of substrate to xylose. The conversion of each substrate to xylose decreased with time what can be attributed to inhibition caused by xylose accumulation.

\section{Catalyst reuse and storage}

The application of a biocatalyst in industry requires the stability of immobilized enzymes through many operational cycles. Long-term storage is also an important characteristic, since increased shelf life is a desired characteristic of bioproducts. The PEIcoated glyoxyl catalyst fully retained its activity after five re-use cycles; once again indicating the enzyme did not suffer subunit dissociation (Figure 8a). During these several hydrolysis-washing-dilution cycles, the curves of product were similar during five-hydrolysis cycles (Figure 8b). From the sixth cycle, the activity gradually decreased and consequently lower product release was observed specially in the beginning of the cycle. The biocatalyst also demonstrated to be very stable during long-term storage since after 6 months under refrigeration it fully retained the hydrolytic activity.

\section{Discussion}

The $\beta$-xylosidase from the ruminal anaerobic bacterium Selenomonas ruminantium is a very well characterized enzyme, and owing to its interesting properties, the enzyme presents high potential for application in industrial processes (Jordan et al. 2007a, 2007b; Jordan 2008; Jordan and Wagschal 2010). Due to its stability at alkaline $\mathrm{pH}$, the enzyme could be easily immobilized on agarose highly activated with glyoxyl groups by carrying out immobilization for $0.5 \mathrm{~h}$ at $\mathrm{pH} \quad 10$ and $25^{\circ} \mathrm{C}$. Immobilization on glyoxyl occurs through the enzyme surface region having the highest density of lysine residues and has been the chosen protocol to obtain very intense enzyme-support multipoint covalent attachment for many enzymes. Besides, prolonged incubation period can increase proteinsupport attachments that could positively influence the catalyst properties in relation to its stability under different conditions (Mateo et al. 2006). Nevertheless, the catalyst prepared by carrying out

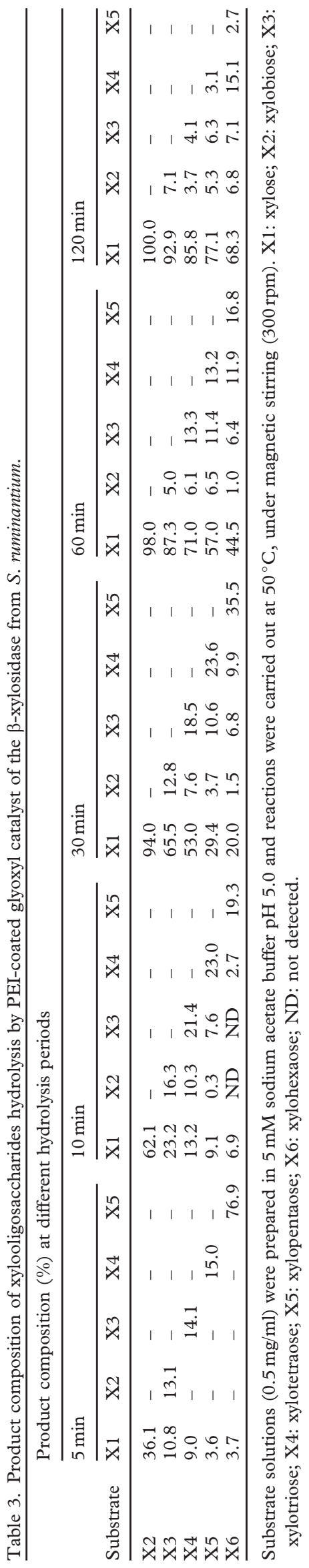



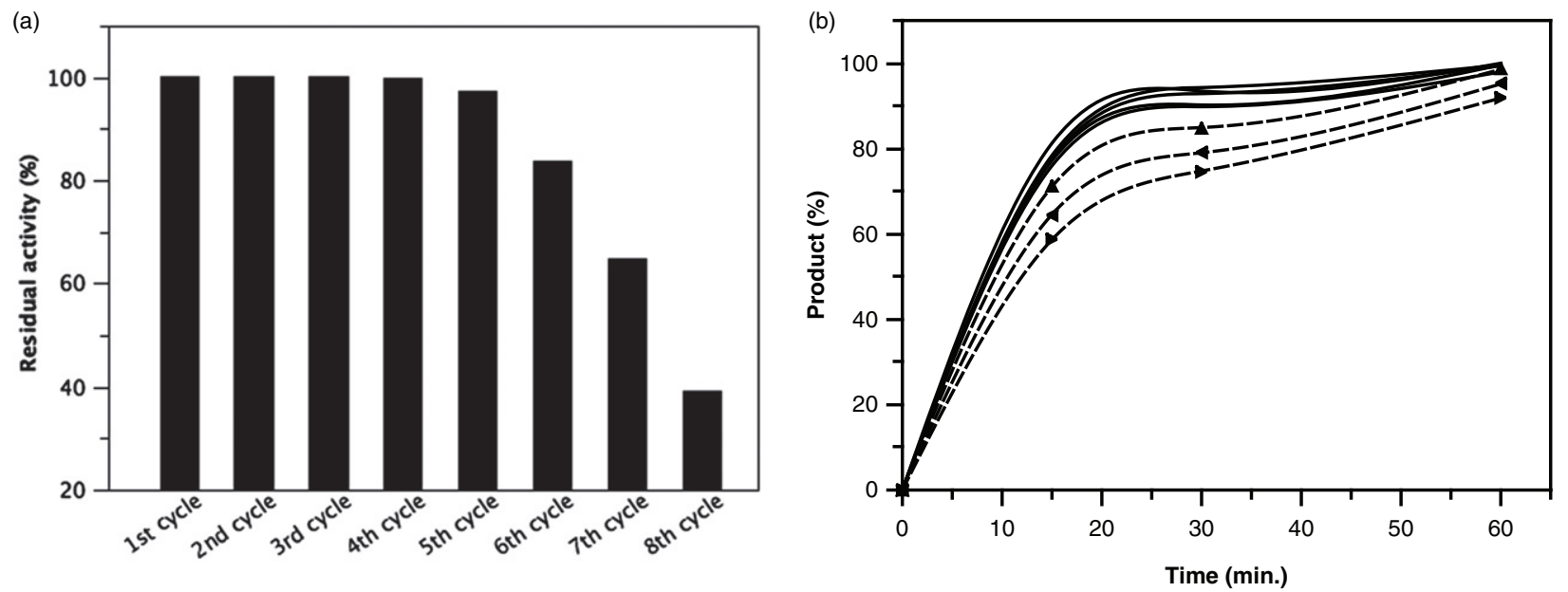

Figure 8. Operational stability (a) and product release (b) from $p$-nitrophenyl $\beta$-D-xylopyranoside hydrolysis by the PEI-coated glyoxyl catalyst of the $\beta$-xylosidase from $S$. ruminantium. The substrate was prepared in $0.05 \mathrm{M}$ sodium acetate buffer $\mathrm{pH} 5.0$ and reaction was carried out at $25^{\circ} \mathrm{C}$. Enzyme activity was assayed in the same buffer at $25^{\circ} \mathrm{C}$. (a) Residual $\beta$-xylosidase activity after consecutive cycles ( $\left.\mathbf{\square}\right)$. (b) Full-lines: product release from the first to the fifth cycle; dashed lines: product release from the sixth $(\boldsymbol{\Delta})$, seventh ( $\mathbf{})$, and eighth cycle $(\bullet)$.

immobilization for $15 \mathrm{~h}$ had lower stability than previously observed, that may be attributed to the distortion of the enzyme structure resulting from excessive attachments (Rodrigues et al. 2013). The marginal stability of biocatalysts has often prevented or delayed their implementation in industry. Consequently, there is great interest in understanding effects of reaction conditions on protein stability, as well as in developing strategies to improve protein stability (Polizzi et al. 2007). In the case of multimeric enzymes, as the tetrameric $S$. ruminantium $\beta$-xylosidase, the stabilization can be considered a special and complex problem in which the subunits dissociation can result in inactivation and even contamination of the product. In this sense, postimmobilization strategies such as coating the catalyst with polymers can stabilize the quaternary structure of immobilized enzymes rendering much more thermostability to the biocatalyst (FernándezLafuente et al. 1999; Bolivar et al. 2009). Thus, covalent immobilization of the $\beta$-xylosidase from $S$. ruminantium initially involves intense but controlled multipoint attachments and full stabilization is achieved by coating its surface with polyethylenimine and aldehyde dextran, resulting in a catalyst that is more than 240-fold more stable than the free enzyme. Free and immobilized enzyme presented similar characteristics as optimum temperature and $\mathrm{pH}$. The catalyst also retained its side activity against $p$ NPAra, a very important characteristic special considering hydrolysis of arabinoxylans, once the presence of side chains may hinder the action of other xylanolytic enzymes involved in xylan degradation (Rahman et al. 2003) The activity of different $\beta$-xylosidases can be associated to the substrate polymerization degree; for example, those from Aspergillus phoenicis (Rizzatti et al. 2001) and Aspergillus versicolor (Andrade et al. 2004) hydrolyze only up to xylotriose, while that from Scytalidium thermophilum (Zanoelo et al. 2004) hydrolyzed up to xylotetraose. Similarly to free enzyme (Jordan et al. 2007a), the immobilized $\beta$-xylosidase from $S$. ruminantium is able to hydrolyze up to xylohexaose, and increasing chain-length reduces hydrolysis rate of the substrate. After immobilization, kinetic parameters of the $\beta$-xylosidase from $S$. ruminantium were affected, i.e., $K_{\mathrm{m}}$ and $V_{\max }$ were 1.6- and 2-fold decreased, respectively. $V_{\max }$ values for other glyoxyl-immobilized enzymes are also reduced such as lactase from Kluyveromyces lactis (Mateo et al. 2004), invertase Saccharomyces cerevisiae (Goulart et al. 2008) and penicillin G acylase from Escherichia coli (Illanes et al. 2010). Despite the fact that immobilization on glyoxyl agarose is considered a very mild system due to the open pore structure and geometric congruence between enzyme and support (Mateo et al. 2006), mass transfer limitations are relevant in the case of immobilized enzymes; besides, factors other than diffusional restrictions, possibly conformational change as a consequence of immobilization, may also be playing a role in determining the catalytic properties of immobilized enzymes (Illanes et al. 2010). Changes in kinetic parameters after immobilization may also lead to changes in inhibition of enzyme (Garcia-Galán et al. 2001), as verified for the lactase from Kluyveromyces lactis, which inhibition by glucose was strongly decreased (Mateo et al. 2004). The immobilized $\beta$-xylosidase 
from $S$. ruminantium is inhibited by xylose, similar to previous observations for the free enzyme (Jordan and Wagschal 2010). The free and immobilized enzyme is also inhibited by glucose, an important consideration particularly in the application of this catalyst for biomass saccharification (Kristensen et al. 2009).

\section{Conclusions}

The tetrameric $\beta$-xylosidase from Selenomonas ruminantium can be successfully immobilized on glyoxyl agarose by a simple protocol. Short period of immobilization is more effective in stabilizing the enzyme, although involvement of all subunits in the covalent immobilization is not achieved. Dextran and, specially, polyethylenimine adequately coat the enzyme subunits, fully maintaining its quaternary structure. The enzyme retained its native properties as optimum $\mathrm{pH}$ and temperature, the activity on xylooligosaccharides up to xylohexaose and its side activity against $p$ NPAra. The immobilized enzyme demonstrated to be active against xylooligosaccharides originated from different xylans, such as commercial beechwood xylan and Cannabis sp xylan, a residue from textile industry. Besides, the prolonged thermostability, the full stability up to five reuse cycles and the prolonged storage stability improve the potential of this biocatalyst to be used in bioprocess to obtain the complete degradation of xylans.

\section{Declaration of interest}

The authors declare not having any conflict of interest.

Part of this work was sponsored by the Spanish Ministry of Science and Innovation (Project BIO2012-36861). C.R.F.T. gratefully acknowledges to CAPES/Ministry of Education, Brazil, through the Program Science Without Borders for the postdoctoral scholarship [Grant 3134-13-0].

\section{ORCID}

César Rafael Fanchini Terrasan (D) http://orcid.org/ 0000-0002-7988-4755

Caio Casale Aragon (D) http://orcid.org/0000-00021138-6290

Douglas Chodi Masui (D) http://orcid.org/00000002-3858-1467

Benevides Costa Pessela (D) http://orcid.org/00000003-1747-0124

Gloria Fernandez-Lorente (D) http://orcid.org/00000002-0756-439X

Eleonora Cano Carmona (D) http://orcid.org/00000002-0230-5735
Jose Manuel Guisan (D) http://orcid.org/0000-00031627-6522

\section{References}

Andrade SV, Polizeli MLTM, Terenzi HF, Jorge JA. 2004. Effect of carbon source on the biochemical properties of $\beta$-xylosidases produced by Aspergillus versicolor. Process Biochem 39:19311938.

Biely P. 1985. Microbial xylanolytic systems. Trends Biotechnol 3:286-290.

Bolivar JM, Rocha-Martin J, Mateo C, Cava F, Berenguer J, Fernandez-Lafuente R, Guisán JM. 2009. Coating of soluble and immobilized enzymes with ionic polymers: full stabilization of the quaternary structure of multimeric enzymes. Biomacromolecules 10:742-747.

Collins T, Gerday C, Feller G. 2005. Xylanases, xylanase families and extremophilic xylanases. FEMS Microbiol Rev 29:3-23.

Dueñas MJ, Estrada P. 1999. Immobilization of $\beta$-xylosidase from Trichoderma reesei QM 9414 on nylon powder. Biocatal Biotrans 17:139-161.

Fernández-Lafuente R, Rodríguez V, Mateo C, Penzola G, Hernández-Justiz O, Irazoqui G, Villarino A, Ovsejevi K, Batista F, Guisán JM. 1999. Stabilization of multimeric enzymes via immobilization and post-immobilization techniques. J Mol Catal B: Enzym 7:181-189.

Garcia-Galán C, Berenguer-Murcia A, Fernandez-Lafuente R, Rodrigues RC. 2001. Potential of different enzyme immobilization strategies to improve enzyme performance. Adv Synth Catal 353:2885-2904.

Goulart AJ, Benedetti ACEP, Tavano OL, Marques DP, Contiero J, Carmona EC, Monti R. 2008. Multipoint immobilization of invertase on agarose: stability and kinetic properties. Curr Trends Biotechnol Pharm 2:462-470.

Guerfali M, Maalej I, Gargouri A, Belghith H. 2009. Catalytic properties of the immobilized Talaromyces thermophilus $\beta$-xylosidase and its use for xylose and xylooligosaccharides production. J Mol Catal B Enzym 57:242-249.

Guisán J. 1988. Aldehyde-agarose gels as activated supports for immobilization-stabilization of enzymes. Enzyme Microb Technol 10:375-382.

Illanes A, González JM, Gómez JM, Valencia P, Wilson L. 2010. Diffusional restrictions in glyoxyl-agarose immobilized penicillin $\mathrm{G}$ acylase of different particle size and protein loading. Electron J Biotechnol 13:1-9.

Jordan DB, Li XL, Dunlap CA, Whitehead TR, Cotta MA. 2007a. Structure-function relationships of a catalytically efficient $\beta$-d-xylosidase. Appl Biochem Biotechnol 141:65-76.

Jordan DB, Li XL, Dunlap CA, Whitehead TR, Cotta MA. 2007b. beta-D-xylosidase from Selenomonas ruminantium of glycoside hydrolase family 43. Appl Biochem Biotechnol 137-140:93-104.

Jordan DB, Wagschal K. 2010. Properties and applications of microbial beta-D-xylosidase featuring the catalytically efficient enzyme from Selenomonas ruminantium. Appl Microbiol Biotechnol 86:1647-1658.

Jordan DB. 2008. beta-D-xylosidase from Selenomonas ruminantium: catalyzed reactions with natural and artificial substrates. Appl Biochem Biotechnol 146:137-149.

Kersters-Hilderson H, Claeyssens M, Van Doorslaer E, Saman E, De Bruyne CK. 1982. Meth Enzymol 83:631-639.

Knob A, Terrasan CRF, Carmona EC. 2010. $\beta$-Xylosidases from filamentous fungi: an overview. World J Microbiol Biotechnol 26:389-407.

Kristensen JB, Felby C, Jørgensen H. 2009. Yield-determining factors in high-solids enzymatic hydrolysis of lignocellulose. Biotechnol Biofuels 2:11.

Laemmli UK. 1970. Cleavage of structural proteins during the assembly of the head of bacteriophage T4. Nature 227:680-685. 
Masui D, Zimbardi A, Souza F, Guimarães LH, Furriel R, Jorge JA. 2012. Production of a xylose-stimulated $\beta$-glucosidase and a cellulase-free thermostable xylanase by the thermophilic fungus Humicola brevis var. thermoidea under solid-state fermentation. World J Microbiol Biotechnol 28:2689-2701.

Mateo C, Monti R, Pessela BC, Fuentes M, Torres R, Guisán JM, Fernández-Lafuente R. 2004. Immobilization of lactase from Kluyveromyces lactis greatly reduces the inhibition promoted by glucose. Full hydrolysis of lactose in milk. Biotechnol Prog 20:1259-1262.

Mateo C, Palomo JM, Fernandez-Lorente G, Guisan JM, Fernandez-Lafuente R. 2007. Improvement of enzyme activity, stability and selectivity via immobilization techniques. Enzyme Microb Technol 40:1451-1463.

Mateo C, Palomo JM, Fuentes M, Betancor L, Grazu V, LópezGallego F, Pessela BCC, Hidalgo A, Fernández-Lorente G, Fernández-Lafuente R, et al. 2006. Glyoxyl agarose: a fully inert and hydrophilic support for immobilization and high stabilization of proteins. Enzyme Microb Technol 39:274-280.

Polizzi KM, Bommarius AS, Broering JM, Chaparro-Riggers JF. 2007. Stability of biocatalysts. Curr Opin Chem Biol 11:220 225.
Rahman AKMS, Sugitani N, Hatsu M, Takamizawa K. 2003. A role of xylanase, alpha-L-arabinofuranosidase, and xylosidase in xylan degradation. Can J Microbiol 49:58-64.

Rizzatti ACS, Jorge JA, Rechia CGV, Polizeli MLTM. 2001. Purification and properties of a thermostable extracellular $\beta$-d-xylosidase produced by a thermotolerant Aspergillus phoenicis. J Ind Microbiol Biotechnol 26:156-160.

Rodrigues RC, Ortiz C, Berenguer-Murcia A, Torres R, Fernández-Lafuente R. 2013. Modifying enzyme activity and selectivity by immobilization. Chem Soc Rev 42:6290-6307.

Saha B. 2003. Hemicellulose bioconversion. J Ind Microbiol Biotechnol 30:279-291.

Sedmak JJ, Grossberg SE. 1977. A rapid, sensitive, and versatile assay for protein using Coomassie brilliant blue G250. Anal Biochem 79:544-552.

Zanoelo FF, Polizeli MLTM, Terenzi HF, Jorge JA. 2004. Purification and biochemical properties of a thermostable xylose-tolerant beta-D-xylosidase from Scytalidium thermophilum. J Ind Microbiol Biotechnol 31:170-176.

Zhang J, Viikari L. 2012. Xylo-oligosaccharides are competitive inhibitors of cellobiohydrolase I from Thermoascus aurantiacus. Bioresour Technol 117:286-291. 